\title{
Do Not Relapse Into Silence
}

\author{
By Ceren Tekin
}

Hello little girl

Would you like to introduce yourself to me?

If it is okay for you, may I hear your voice?

I would like to learn with you and from you

Did that surprise you?

Yes, I am older than you, but I think you can teach me

I do not know your stories

But if you share them with me, I will be very happy

When I hear you, you can give me hope and inspiration

In addition, you can give hope and inspiration to the others

Thus, please do not relapse into silence

Never forget that

Your voice, your ideas, your opinion, yourself and your life

They are so precious

So, never let anyone take them away from you

And when you want to get help, do not hesitate

Never quit certainty for hope

There are still good people in the world

Yes, you may meet with bad people too

Therefore, you must be strong, believe in yourself and have confidence

Never forget that

You are very beautiful and special

It's so wonderful to meet you

Again, never forget that

The world needs you

*I was inspired to write this poem after viewing the video "Cherry Kingsley

Recognizing the Person" (2002) in an undergraduate class at Carleton University. 